\title{
KEBIJAKAN ALOKASI DANA DESA (ADD) DALAM RANGKA MENGOPTIMALKAN PEMBANGUNAN DESA
}

\author{
Oleh \\ Restu Widyo Sasongko \\ Institut Pemerintahan Dalam Negeri \\ bmwclassic27@gmail.com
}

\begin{abstract}
$T$ e Village Fund Allocation Policy within the framework of village development is to improve the welfare of rural communities and the quality of human life and poverty reduction. One measure of increasing community welfare and decreasing poverty in a region is the large number of prosperous families in the area. One source of village income which is the budget allocation from the State Budget (APBN) is the Village Fund. Given the Village Fund's source is from the State Budget (APBN), then to optimize its use the government has the authority to set priorities for the use of the Village Fund to support development programs and empower village communities. The Village Fund Allocation Policy (ADD) is a balancing fund originating from the district/city government handed over to the village government which is expected to be the main buffer for the implementation of community empowerment and village development so as to improve community welfare, through this fund the village government can optimize development which is the main goal for the empowerment and welfare of the community in a village, it means that the government budget given to the village is for development facilities and village empowerment as one of the institutions contributing in the format of governance.
\end{abstract}

Keywords: village development. state budget, community

\begin{abstract}
Abstrak
$\mathrm{K}^{\mathrm{e}}$ ebijakan Alokasi Dana Desa dalam kerangka pembangunan desa adalah meningkatkan kesejahteraan masyarakat desa dan kualitas hidup manusia serta penanggulangan kemiskinan. Salah satu ukuran dari peningkatan kesejahteraan masyarakat serta menurunnya angka kemiskinan suatu daerah adalah banyak sedikitnya jumlah keluarga sejahtera di daerah tersebut. Salah satu sumber pendapatan desa yang merupakan alokasi anggaran dari Anggaran Pendapatan dan Belanja Negara (APBN) adalah Dana Desa. Mengingat sumber Dana Desa adalah dari APBN, maka untuk mengoptimalkan penggunaannya pemerintah mempunyai kewenangan untuk menetapkan prioritas penggunaan Dana Desa untuk mendukung program pembangunan dan pemberdayaan masyarakat desa. Kebijakan Alokasi Dana Desa (ADD) merupakan dana perimbangan yang berasal dari pemerintah kabupaten/kota diserahkan pada pemerintah desa yang diharapkan menjadi penyangga utama pelaksanaan pemberdayaan masyarakat dan pembangunan desa sehingga dapat meningkatkan kesejahteraan masyarakat, melalui dana ini pemerintah desa bisa mengoptimalkan pembangunan yang mana tujuan utamanya untuk pemberdayaan serta menyejahterakan masyarakat yang ada di sebuah desa, artinya anggaran pemerintah yang diberikan kepada desa adalah untuk fasilitas pembangunan dan pemberdayaan desa sebagai salah satu lembaga yang andil dalam format kepemerintahan.
\end{abstract}


Kata kunci: alokasi dana desa, pembangunan desa. anggaran pendapatan dan belanja negara, komunitas

\section{PENDAHULUAN}

$\mathrm{D}$

esa adalah representasi dari kesatuan masyarakat hukum terkecil yang telah ada dan tumbuh seiring dengan perkembangan kehidupan masyarakat Indonesia. Kenyataan tersebut sekaligus menempatkan desa sebagai salah satu entitas tidak terpisahkan serta diakui eksistensinya dalam sejarah dan perkembangan tata pemerintahan Indonesia. Dalam penyelenggaraan pemerintahan daerah, Indonesia terdiri atas beberapa daerah provinsi. Selanjutnya, daerah provinsi terdiri atas beberapa daerah kabupaten/kota. Dalam setiap daerah kabupaten/kota terdapat satuan pemerintahan terendah, yaitu desa dan kelurahan. Meskipun samasama merupakan satuan pemerintahan terendah, ada perbedaan status antara desa dan kelurahan.

Desa adalah satuan pemerintahan yang diberi hak otonomi adat sehingga merupakan badan hukum, sedangkan kelurahan adalah satuan pemerintahan administrasi yang hanya merupakan kepanjangan tangan dari pemerintah kabupaten/kota. Jadi, kelurahan bukan badan hukum melainkan hanya sebagai tempat beroperasinya pelayanan pemerintahan dari pemerintah kabupaten/ kota di wilayah kelurahan setempat. Sedangkan desa adalah wilayah dengan batasbatas tertentu sebagai kesatuan masyarakat hukum (adat) yang berhak mengatur dan mengurus urusan masyarakat setempat berdasarkan asal-usulnya (Nurcholis, 2011).

Keberadaan desa, baik sebagai satuan pemerintahan maupun sebagai kesatuan masyarakat hukum sangat penting dalam penyelenggaraan negara. Sebagai satuan pemerintahan, desa menjadi ujung tombak (front linier) pelayanan kepada masyarakat. Adapun sebagai kesatuan masyarakat hukum, desa menjadi fondasi kokoh bagi sistem kemasyarakatan bangsa Indonesia serta menjadi landasan kuat untuk pengembangan sistem politik, ekonomi, sosial budaya, dan pertahanan keamanan. Mengingat begitu luas dan beragamnya kesatuan masyarakat, maka dikenal pula sebutan lain untuk desa di beberapa daerah, seperti Gampong di Aceh, Nagari di Sumatera Barat, Kepenghuluan di Riau, dan Kampung di Papua.

Dalam membangun basis yang kuat bagi demokrasi, partisipasi rakyat, keadilan, dan pemerataan pembangunan sekaligus memperhatikan kebutuhan masyarakat lokal yang berbeda-beda, pemerintah bersama lembaga legislatif mengesahkan Undang-Undang No. 32 Tahun 2004 tentang Pemerintahan Daerah dan Undang-Undang No. 33 Tahun 2004 tentang Perimbangan Keuangan antara Pemerintah Pusat dan Pemerintah Daerah. Unsur penting dalam kedua undang-undang ini adalah bahwa penguasa daerah (gubernur, bupati, Wali kota) harus lebih bertanggung jawab kepada rakyat di daerah. Berdasarkan UU No. 32 Tahun 2004 daerah diberikan otonomi yang seluas-luasnya untuk mengurus semua penyelenggaraan pemerintah di luar kewenangan pemerintah pusat untuk membuat kebijakan daerah yang berhubungan dengan peningkatan pelayanan dan pemberdayaan masyarakat, serta otonomi yang bertanggung jawab dan nyata. Dalam melaksanakan apa yang menjadi urusannya berdasarkan kewenangan yang diberikan dan karakteristik dari suatu wilayah sedangkan bertanggung jawab adalah otonomi yang dalam penyelenggaraannya harus sejalan dengan maksud dan tujuan pemberian otonomi yaitu memajukan daerah dan meningkatkan kesejahteraan rakyat.

Kebijakan pemberian Alokasi Dana Desa merupakan wujud pemenuhan hak desa 
dalam rangka penyelenggaraan otonomi desa. Alokasi Dana Desa bersumber dari bagian dana perimbangan keuangan pusat dan daerah yang diterima oleh kabupaten di luar Dana Alokasi Khusus (DAK) setelah dikurangi belanja pegawai. Sasaran Alokasi Dana Desa adalah seluruh desa yang ada dalam wilayah kabupaten setempat. Penggunaan Alokasi Dana Desa 30\% untuk mendukung penyelenggaraan pemerintahan desa dan penguatan peran kelembagaan masyarakat desa, sedangkan $70 \%$ untuk mendukung program pemberdayaan masyarakat desa.

\section{TINJAUAN PUSTAKA}

Adanya Undang-Undang No. 6 Tahun 2014 tentang Desa, saat ini hampir semua mata tertuju pada desa. Mulai dari para pejabat, akademisi, politikus, pengamat maupun aktivis Non Government Organization (NGO) samasama ingin melihat desa dari dekat, hal ini dikarenakan bagaimana pengaruh dinamika pembangunan desa saat ini. Besarnya perhatian yang diberikan terhadap desa didasari adanya pemberian dana desa yang jumlahnya makin besar oleh Pemerintah Pusat. Setiap tahun Pemerintah Pusat telah menganggarkan Dana Desa yang cukup besar. Pada 2015, Dana Desa dianggarkan sebesar Rp20,7 triliun dengan rata-rata setiap desa mendapatkan alokasi sebesar Rp280 juta. Pada 2016, Dana Desa meningkat menjadi Rp46,98 triliun dengan rata-rata setiap desa sebesar Rp628 juta dan pada 2017 kembali meningkat menjadi Rp60 triliun dengan rata-rata setiap desa menerima Rp800 juta. Sesuai dengan tujuan pembangunan desa sebagaimana amanat Undang-Undang No. 6 Tahun 2014 yaitu meningkatkan kesejahteraan masyarakat desa dan kualitas hidup manusia serta penanggulangan kemiskinan, maka pengalokasian Dana Desa lebih banyak mempertimbangkan tingkat kemiskinan.
Hal ini semakin menunjukkan bahwa Pemerintah serius memajukan desa. Keseriusan Pemerintah untuk memajukan desa tentunya tidak hanya mengandalkan ketersediaan regulasi. Namun Pemerintah ini butuh dukungan, agar tujuan pemerintah memperbaiki dan memajukan desa dapat segera terwujud melalui subsidi dana desa. Untuk mendukung suksesnya pengelolaan keuangan desa, butuh para kepala desa dan perangkat desa yang punya kapasitas. Kepala dan aparat desa harus paham dan mengerti tentang regulasi terhadap desa. Jika tidak, pasti pengelolaan keuangan desa akan mengalami masalah serius ke depannya.

\section{Pengelolaan Keuangan Desa}

Pemerintah selaku penyelenggara dan pengelolaan Keuangan Desa, pemerintah desa tidak hanya mengelola dana desa yang bersumber dari APBN. Selain mengelola dana transfer Pemerintah pusat, pemerintah desa juga mengelola Alokasi Dana Desa (ADD), Bagi Hasil Pajak dan Retribusi Daerah, Bantuan Keuangan Provinsi serta pendapatan asli desa (PADes).

Secara regulatif semua keuangan desa ini akan terdokumentasi dalam bentuk APBDes. Yang pengelolaannya mengikuti berbagai petunjuk peraturan perundangundangan. Ini artinya, pemerintah desa tidak lagi sembarangan mengelola keuangan desa. Sekalipun otoritas sebagai kuasa pengguna anggaran dan pengguna anggaran ada pada seorang kepala desa.

Sesuai dengan ketentuan Pasal 1 ayat (6), Permendagri No. 113 Tahun 2014, pengelolaan keuangan desa adalah keseluruhan kegiatan yang meliputi perencanaan, pelaksanaan, penatausahaan, pelaporan, dan pertanggungjawaban keuangan desa. Batasan ini sungguh jelas dan poin pertama yang patut kita pahami bersama adalah perencanaan. Perencanaan telah menjadi syarat dasar bagi pengelolaan keuangan desa. Oleh sebab itu, sebagai 
penyelenggara pemerintah desa wajib menyediakan dokumen perencanaan sebelum mengelola keuangan desa. Ada tiga jenis dokumen penting perencanaan yang mesti disediakan oleh pemerintah desa. Ketiga dokumen tersebut adalah RPJMDes, RKPDes dan APBDes. Legalitas ketiga dokumen ini telah diatur dalam Permendagri No. 113 Tahun 2014 tentang Pengelolaan Keuangan Desa dan Permendagri No. 114 Tahun 2014 tentang Pedoman Pembangunan Desa serta peraturan terkait lainnya tentang desa. Tanpa dokumen ini pemerintah desa tidak boleh mengelola keuangan desa. Jika pemerintah desa memaksakan diri, pasti akan timbul masalah dalam pengelolaan keuangan desa.

\section{Masalah Keuangan Desa}

Ada beberapa masalah dalam pengelolaan keuangan desa selama ini. Pertama, keterbatasan regulasi. Bahwa good will dan political will pemerintah dengan menghadirkan regulasi khusus tentang desa sampai saat ini tidak cukup membantu kepala desa dan perangkatnya.Kondisi ini terlihat jelas dari adanya keterlambatan dan kesulitan pemerintah desa dalam penyusunan perencanaan kegiatan dan keuangan desa. Hampir semua perundangundangan desa yang memerintahkan adanya turunan peraturan melalui Perda dan Perbup sama sekali belum ditindaklanjuti. Contoh konkret adalah tidak adanya Perbup tentang perencanaan desa sebagai perintah Pasal 8 9 Permendagri No. 114 Tahun 2014 tentang Pedoman Pembangunan Desa, Perbup tentang daftar kewenangan berdasarkan hak asal-usul dan kewenangan lokal berskala desa sebagai perintah Pasal 18 Permendesa No. 1 Tahun 2015, Perbup tentang teknis penggunaan dana desa (APBN) tahun 2016 sebagai perintah Pasal 11 Permendesa No. 21 Tahun 2015 tentang Prioritas Penggunaan Dana Desa Tahun Anggaran 2016.Peraturan lain yang mesti disediakan oleh Bupati melalui SKPD terkait, misalnya Perbup tentang pengadaan barang dan jasa di desa, serta Perbup tentang pengelolaan keuangan desa, padahal, turunan regulasi-regulasi ini sangat penting untuk membantu kepala desa dan perangkatnya. Semua regulasi yang ada saat ini sifatnya masih Abstrak, yang diatur adalah hal-hal bersifat umum.Persoalan yang sering ditemukan di lapangan adalah masih banyak administrasi pelaporan dan pertanggungjawaban yang belum dikerjakan, misalnya Laporan Penyelenggaraan Pemerintah Desa (LPPD) maupun Laporan Keterangan Pertanggungjawaban (LKPj) Kepala Desa.

Kedua, Pengawasan, pengelolaan keuangan desa masih minim pengawasan dan kurangnya pengetatan terhadap penggunaan anggaran. Fakta lapangan menunjukkan bahwa partisipasi publik terhadap pengelolaan keuangan desa masih terbatas dan kurang fokus. Pengawasan lebih mengandalkan prosedur regular. Yang diutamakan hanyalah peran Badan Permusyawaratan Desa (BPD).

\section{PEMBAHASAN}

\section{Alokasi Dana Desa (ADD)}

Alokasi Dana Desa adalah dana yang bersumber dari Anggaran Pendapatan dan Belanja Daerah (APBD) Kabupaten yang dialokasikan dengan tujuan pemerataan kemampuan keuangan antardesa untuk mendanai kebutuhan desa dalam rangka penyelenggaraan pemerintahan dan pelaksanaan pembangunan serta pelayanan masyarakat. Alokasi Dana Desa merupakan perolehan bagian keuangan desa dari kabupaten yang penyalurannya melalui Kas Desa. Alokasi Dana Desa adalah bagian dana Perimbangan Keuangan Pusat dan Daerah yang diterima oleh Kabupaten.

Adapun tujuan dari Alokasi Dana Desa (ADD) adalah sebagai berikut.

1) Meningkatkan penyelenggaraan pemerintahan desa dalam melaksanakan 
pelayanan pemerintahan, pembangunan, dan kemasyarakatan sesuai kewenangannya.

2) Meningkatkan kemampuan lembaga kemasyarakatan di desa dalam perencanaan, pelaksanaan, dan pengendalian pembangunan secara partisipatif sesuai dengan potensi desa.

3) Meningkatkan pemerataan pendapatan, kesempatan bekerja dan kesempatan berusaha bagi masyarakat desa.

4) Mendorong peningkatan swadaya gotong royong masyarakat desa.

Pemerintah mengharapkan kebijakan Alokasi Dana Desa ini dapat mendukung pelaksanaan pembangunan partisipatif berbasis masyarakat dalam upaya pemberdayaan masyarakat perdesaan sekaligus memelihara kesinambungan pembangunan di tingkat desa. Dengan adanya Alokasi Dana Desa, desa memiliki kepastian pendanaan sehingga pembangunan dapat terus dilaksanakan tanpa harus terlalu lama menunggu datangnya dana bantuan dari pemerintah pusat.

\section{Siklus Keuangan Desa}

a. Penyusunan anggaran

b. Pembukuan dan perhitungan

c. Pelaporan (perhitungan) realisasi anggaran APBDes:

$$
\begin{array}{ll}
\checkmark & \text { Pendapatan } \\
\checkmark & \text { Belanja } \\
\checkmark & \text { Pembiayaan }
\end{array}
$$

\section{Penetapan Alokasi Dana Desa (ADD)}

Alokasi Dana Desa (ADD) didasarkan pada ketetapan-ketetapan berikut ini.

a. Penetapan dan hasil perhitungan alokasi dana desa setiap tahun ditetapkan dengan peraturan bupati.

b. Penetapan dan hasil perhitungan Alokasi Dana Desa dimaksud diberitahukan kepada desa selambat-lambatnya pada Agustus setiap tahunnya.

c. Data variabel independen utama dan variabel independen tambahan selambat-lambatnya dikirim oleh Tim Pendamping Tingkat Kecamatan kepada Tim Fasilitasi Kabupaten pada Maret untuk penghitungan Alokasi Dana Desa tahun berikutnya.

\section{Penggunaan Alokasi Dana Desa}

Alokasi Dana Desa digunakan untuk penyelenggaraan pemerintah desa sebesar $30 \%$ dan untuk pemberdayaan masyarakat desa sebesar $70 \%$ dari jumlah penerimaan ADD.

ADD yang digunakan belanja aparatur dan operasional desa yaitu untuk membiayai kegiatan penyelenggaraan pemerintahan desa dengan prioritas sebagai berikut.

a) Peningkatan sumber daya manusia kepala desa dan perangkat desa meliputi pendidikan, pelatihan, pembekalan, studi banding.

b) Biaya operasional tim pelaksana bidang pemerintahan.

c) Biaya tunjangan kepala desa, perangkat desa, tunjangan dan operasional BPD, honor ketua RT dan RW serta penguatan kelembagaan RT/RW.

d) Biaya perawatan kantor dan lingkungan kantor kepala desa.

e) Biaya penyediaan data dan pembuatan pelaporan, pertanggungjawaban meliputi:

i. Pembuatan/perbaikan monografi, peta, data dinding, dll.

ii. Penyusunan APBDes, LPPD, dan LKPJ, pelaporan dan pertanggungjawaban penggunaan Alokasi Dana Desa (ADD).

iii. Biaya lain-lain yang perlu dan mendesak, misalnya Penanganan keadaan darurat seperti bencana alam, kebakaran, dan sebagainya. 


\section{PemberdayaAn Masyarakat}

Alokasi Dana Desa (ADD) yang digunakan untuk membiayai kegiatan pemberdayaan masyarakat dengan prioritas kegiatan seperti:

a. Biaya Pemberdayaan Manusia dan Institusi.

Penggunaannya meliputi:

i. Pembinaan Keagamaan.

ii. Peningkatan kemampuan Pengelola Lembaga Usaha Milik Desa (BUMDes, LPMD, dsb) dalam rangka meningkatkan pendapatan masyarakat.

iii. Pelayanan kesehatan masyarakat terutama pada penanganan Gizi Balita melalui Posyandu.

iv. Menunjang kegiatan Sepuluh Program Pokok PKK, Kesatuan Gerak PKK dan UP2K-PKK.

v. Menunjang kegiatan Anak dan Remaja antara lain pengadaan sarana TPK, TK, sarana Olahraga, Karangtaruna dll.

vi. Biaya Musrenbang dan serap aspirasi tingkat dusun/lingkungan.

vii. Peningkatan keamanan dan ketenteraman Desa.

b. Biaya Pemberdayaan Lingkungan. Penggunaannya meliputi:

i. Pembangunan/biaya perbaikan sarana publik dalam skala kecil atau sarana perekonomian Desa seperti pembuatan jalan, talud/ irigasi, jembatan, los pasar, lumbung pangan dll.

ii. Untuk penghijauan/tanaman hortikultura.

c. Biaya Pemberdayaan usaha/ekonomi, Penggunaannya meliputi:

i. Pengembangan lembaga simpan pinjam melalui modal usaha dalam bentuk BUMDes, UED-SP, LKPMD,
Badan Perkreditan Desa dan lembaga lainnya.

ii. Pengembangan usaha mikro dan usaha kecil masyarakat antara lain melalui penambahan modal usaha serta budi daya pemasaran produk.

iii. Biaya untuk pengadaan pangan.

\section{Pengelolaan Alokasi Dana Desa}

Untuk meminimalisir bahkan mencegah terjadinya penyalahgunaan Alokasi Dana Desa ini, maka pemerintah kabupaten menetapkan pengaturan dan pengelolaan yang harus ditaati oleh setiap pengelola Alokasi Dana Desa di setiap desa yang adalah sebagai berikut.

a. Pengelolaan Alokasi Dana Desa dilakukan oleh Kepala Desa yang dituangkan ke dalam Peraturan Desa tentang Anggaran Pendapatan dan Belanja Desa.

b. Pengelolaan Keuangan Alokasi Dana Desa merupakan bagian tidak terpisahkan dari Anggaran Pendapatan dan Belanja Desa beserta lampirannya.

c. Seluruh kegiatan yang didanai oleh Alokasi Dana Desa harus direncanakan.

d. Alokasi Dana Desa dilaksanakan dengan menggunakan prinsip efisien dan efektif, terarah, terkendali serta akuntabel dan bertanggung jawab.

e. Bupati melakukan pembinaan pengelolaan keuangan desa.

f. Alokasi Dana Desa merupakan salah satu sumber pendapatan desa.

g. Pengelolaan Alokasi Dana Desa dilakukan oleh Pemerintah Desa yang dibantu oleh lembaga kemasyarakatan di desa.

\section{Permasalahan dan Desain PERBaikan}

a. Analisis permasalahan

Dari seginegara, demokrasi mengajarkan bahwa partisipasi sangat dibutuhkan untuk membangun pemerintahan yang 
akuntabel, transparan, terbuka dan jujur. Ada beberapa masalah yang harus dianalisis dan dipecahkan antara lain dalam pengelolaan Alokasi Dana Desa (ADD) ada sedikit kekurangan dari segi penyusunan anggaran yang didasarkan pada adat kebiasaan yang tidak sesuai dengan program kerja yang telah direncanakan.

b. Pemecahan masalah dan desain perbaikan antara lain:

i. Pemerintah Daerah kabupaten/kota harus memberikan pendampingan dalam rangka penyelesaian pertanggungjawaban dan laporan keuangan desa, karena keterbatasan SDM Desa.

ii. Kerja sama antara pengurus dan masyarakat desa

iii. Memberikan penyuluhan tentang pemberdayaan masyarakat desa.

iv. Membuka usaha koperasi desa.

\section{SIMPULAN DAN SARAN}

\section{SimpUlan}

Pengelolaan Alokasi Dana Desa akan berjalan baik apabila proses perencanaan, proses implementasi, proses evaluasi dilaksanakan secara jujur, transparan, dan bertanggung jawab. Alokasi Dana Desa adalah dana rakyat, maka sudah sewajarnya bila rakyat mengetahui informasi dana tersebut.

Dana yang diberikan oleh pemerintah pusat kepada pemerintah daerah khususnya desa, digunakan sebagaimana mestinya agar tidak ada dana yang mengalir dengan tujuan yang bersifat pribadi, karena jika dana yang digunakan sesuai dengan ketentuannya maka kesejahteraan dan fasilitas yang ada di daerah bisa terakses dengan baik dan dapat menyejahterakan masyarakatnya, sesuai dengan tujuan yang telah ditentukan sebelumnya.

\section{SARAN}

Adapun saran yang bisa disampaikan ialah dengan adanya bantuan yang disediakan oleh pemerintah dengan tujuan yaitu untuk menyejahterakan masyarakat di daerah, terutama desa terpencil dan perbatasan harusnya bisa diapresiasi dan dimanfaatkan untuk membangun daerah tersebut menjadi lebih baik lagi, agar kehidupan masyarakat bisa menjadi lebih sejahtera.

Dana yang digunakan haruslah dilaksanakan dengan transparan, terbuka dan jujur agar masyarakat bisa mengetahui dan mengawasi dana tersebut agar tidak dipakai untuk hal di luar program yang telah direncanakan sebelumnya, sehingga tidak ada yang namanya rasa saling curiga di antara masyarakat dan aparat yang berwenang. Apabila dana tersebut telah digunakan sesuai dengan ketentuannya yaitu untuk kepentingan bersama, hendaklah dijaga bersama-sama agar tidak ada kerusakan yang terjadi akibat oknum yang tidak bertanggung jawab sehingga fasilitas yang digunakan bisa bertahan lebih lama.

Harus jelas sumber anggaran untuk insentif bagi para tim pengelola keuangan desa. Hal yang perlu ketahui bersama, bahwa pemerintahan desa tidak bisa paham dan menjadi mampu dengan sendirinya. Tanpa ada intervensi positif dan pendampingan. Tidak boleh melakukan pembiaran terhadap pemerintah desa. Di sinilah pemerintah daerah dan pendamping profesional harus hadir.

\section{DAFTAR PUSTAKA}

Irawan, Nata 2017. Tata Kelola Pemerintahan Desa Era UU Desa. Jakarta. Yayasan Pustaka Obor Indonesia.

Undang-Undang No. 43 Tahun 2014 tentang Pelaksanaan UU tentang Desa.

Undang-Undang No. 6 Tahun 2014 tentang Desa

Undang-Undang No. 72 Tahun 2015 tentang Pemerintahan Desa. 
Undang-Undang No. 32 Tahun 2004 tentang Pemerintahan Daerah.

Permendagri No. 84 Tahun 2015 tentang Susunan Organisasi dan Tata Kerja Pemerintahan Desa.

Dodi Zainudin, 2017. Alokasi Dana Desa Dalam Rangka Mengoptimalkan Pembangunan Desa.

\section{Sumber Lain}

http: $\quad / /$ makalahlaporanterbaru1.blogspot. co.id/2012/04/penyusunan-rencana biaya-dan-pendanaan.html (diakses 20 April 2018) http: //kupang.tribunnews.com/2016/04/08/ masalah-pengelolaan-keuangan-desa? page $=1$ dan 2 (diakses 30 April 2018)

http: //tirto.id/mengurai-benang-kusutpengelolaan-dana-desa (diakses 2 Mei 2018)

www.cingcin.desa.id 